DOI: 10.20472/IAC.2020.053.012

ORESTE NAPOLITANO

University of Naples Parthenope, Italy

SALVATORE CAPASSO

University of Naples Parthenope, Italy

ANA LAURA VIVEROS

Universidad Nacional Autónoma de México, Mexico

\title{
FINANCIAL CONDITIONS INDEX AS A PREDICTOR IN LOW-INFLATION ENVIRONMENT
}

\begin{abstract}
:
The nature of the financial crisis in 2008 imposed new challenges for macroeconomic theory and policy-makers. In this context, a financial conditions index $(\mathrm{FCl})$ could be a useful tool to identify the state of financial conditions in a country. We construct a $\mathrm{FCl}$ for Mexico to analyse the role of prices of financial assets in the formulation of monetary policy under the inflation-targeting regime. We estimate $\mathrm{FCls}$ by two different methodologies using monthly data from 1990 to 2017. The variables are considered according to the mechanism of transmission of monetary policy and incorporating other important financial variables, those characterise developing countries. Our results show that $\mathrm{FCl}$ is a good predictor in a low/non-inflation environment.
\end{abstract}

\section{Keywords:}

Financial Conditions, Monetary policy, Vector autoregressive models

JEL Classification: E52, E58, C01 